\title{
Commercial Sex Work Phenomenon: Issues in Perspectives
}

\author{
Kola O. Odeku \\ Faculty of Management and Law, School of Law, \\ University of Limpopo, South Africa \\ E-mail:kooacademics@gmail.com
}

Doi:10.5901/mjss.2013.v4n13p861

\begin{abstract}
One of the social vices that continue to generate unending debates is the issue of sex workers or prostitution. Though it is generally recognised as one of the oldest professions but at every stage there have been calls by various local rulers' religious leaders and governments to ban the trade. The prohibition has constantly reoccurred in virtually all discourse be it in the local or international arena. However, the proponents in support have constantly been at the forefront and usually canvassed arguments in favour of the trade to be legalised based on various reasons. As it will unfold in this article, some countries have legalised it while others outlawed it. This article looks at the phenomenon of this trade and raised issues which were discussed in different perspectives.
\end{abstract}

Keywords: Prostitution, legalisation, prohibition, morality, views.

\section{Introduction}

There have been ongoing heated debates on the issues surrounding the status and phenomenal of commercial sex work in South Africa (Gelb, 2004). The debates became more vigorous and robust shortly before the 2010 World Cup hosted by South Africa. There were perceptions that there would be a drastic increase in prostitution during the mundial hence calls for prostitution to be legalised and regulated to help control Acquired immuned deficiency sydrome (AIDS) ,Sexually transmitted diseases(STDs )and for the protection of sex workers (British Broadcasting Corporation(BBC News, )2008). These moves met stiff resistances from different groups that opposed prostitution. However, prior to and after the events, there was little evidence of increased prostitution, and no changes were made to the laws. This is because the society has not taken any stand for or against whether prostitutes should be considered as workers and their status recognised under the various labour laws. Narrating the extent of the controversies surrounding the issues of the status of sex workers in the society, the court, in a recent Canadian case of Canada (Attorney General) v. Bedford, 2012 ONCA 186, has observed that "Prostitution is a controversial topic, one that provokes heated, heartfelt debates about morality, the court wrote in its opinion. It is not the court's role to engage in that debate." As a result of this division, those who engage in the trade have been left more vulnerable and are usually at the mercy of law enforcement agents who most times, take undue advantage of them (Martell, 2012).

Often times, laws which criminalise prostitution are not effectually applied but merely used by the law enforcement agents to intimidate and extort money from the victims (Katyal and William, 2006). This assertion is reinforced by the observation of Goodyear (2009), who said "as with other 'vices' and moral legislation, enforcement is often approached with blind eyes, and referred to as containment or tolerance, and invites corruption.

To a greater extent, there has been lack of the prosecution of the crime generally in courts (Kelly et al. 2000). It is pertinent to point out that the act is generally committed between two consenting adult persons in the privacy of their own homes, rooms and or organised secluded areas ( Hubbard, 2001).

Another ensuing contention is that the criminalisation of the act is usually geared to target women not men and this discriminates unfairly against the women who are mostly victims and are vulnerable in such matters (Tomsen, 2013). However, some commentators have expressed their views that the laws must be tightened to curb the practice and its growth but these views were expressed mostly from the moral perspectives (Melossi, 2000).

\section{Conceptual Clarifications and the Review of the Literature}

There has been serious contestation with regard to the issues of law and morality, in particular is the issue of sexual 
morality (Hunt, 1999). It is therefore difficult to draw the line on what constitutes a criminal act. While Devlin posits that moral values are universal, and deviation threatens social order justifying criminal sanctions (Plauché, 2006). Hart, in contrast was of the view that there must be demonstrable harm to an individual as justification (Bassham, 2012). However, Raz argues that the State cannot make people moral, while recognising that the promotion of autonomy may require coercion to prevent harm under certain circumstances (Raz, 1986). A demographic and geographical location of each country seems to dictate what is moral and what crime is. Some countries abhor prostitution while others embrace it and even codified their modus operandi (Cohen, 2006).

Weitzer (2009:4-5) described different perception on the sex work phenomena captured at different stages of history from the ancient times to the modern times thus "the poles of condemnation and normalisation are reflected in two paradigms in the social sciences. One of these is the oppression paradigm which holds that sex work is a quintessential expression of patriarchal gender relations and male domination. The most prominent advocates of this position go further claiming that exploitation, subjudication and violence against women are intrinsic to and ineradicable from sextranscending historical time period, national context and types of sexual commerce. These indictments apply equally to pornography, prostitution, stripping and other commercial sex industries, which is precisely the goal of those who adopt the oppression paradigm." (Weitzer, 2009).

For example, Assyrian law distinguished prostitutes from other women by their differences in dressing in the code of Assura. "If the wives of a man or the daughters of a man go out into the street, their heads are to be veiled. The prostitute's is not to be veiled. Maidservants are also not to veil themselves. Harlots and maidservants wearing head veils shall have their garments seized and 50 blows inflicted on them and bitumen (asphalt or tar like substance) poured on their heads."

A decree of Recared, Catholic king of the Visigoths of Spain (596-601) absolutely prohibited prostitution. "Girls and women born of free parents convicted of practising prostitution or inducing debauchery offence for the first time will be condemned and flogged (300 strokes) and will be ignominiously expelled from the town." (Mizuta and Mulvey-Roberts, 1994).

"Alfonso IX's ....[Castilian] ruler 11881230).... regulations on prostitution are among the earliest in Europe. In a section of code... he concentrated on those who profited from prostitutes... Those involved in selling prostitutes were to be exiled from the kingdom; landlords who rented rooms to prostitutes were to have their houses impounded and also pay a fine; brothel keepers had to free the women in their brothels... and find husbands for them or else suffer the possibility of execution; husbands who prostituted their wives were to be executed. Pimps are to flogged for first time offense and if they persist, they were sent to the galleys as convicts. Women who supported pimps were to be publicly whipped and have the clothes they wore destroyed." (Bullough and Bullough, 1978),

In 1469, " a special ordinance of Henry IV, King of Castila was launched against the men who acting as procurers associated themselves with the prostitutes. Such men were called ruffians. The ruffian's punishment for first time offense was to recieve 100 lashes, for the second time offense, they were to be banished for life; for the third they were to behung." (Mizuta and Mulvey-Roberts1994).

"A new law had come into force on Jan. 1, 2009 in Norway making the purchase of sex illegal. Norwegian citizens caught paying for prostitutes at home or abroad could face a hefty fine or a six-month prison sentence, authorities say. The prison sentence could be extended to three years in cases of child prostitution." (BBC News, 2009). Tough new measures go further than similar ones introduced by other Nordic countries such as Sweden and Finland. "Norwegian police have been authorised to use wire-tapping devices to gather evidence. Reformed prostitutes will be offered access to free education and health treatment for those with alcohol or drugs problems." (BBC News, 2009).

"Taiwan began a process of legalizing prostitution on Wednesday [June 24, 2009] making the island the latest place in the world to decriminalize the world's oldest profession." (BBC News, 2009). Taiwan outlawed prostitution 11 years ago, but older sections of the capital, Taipei still teemed with underground sex workers in bars and night clubs on the upper floors of high-rise buildings. The Collective of Sex Workers and Supporters, a Taipei-based advocacy group, estimates that 600,000 people are involved in sex-related jobs."(Reuters, 2009).

In India, prostitution (the exchange of sexual services for money) is legal, but a number of related activities, including soliciting in a public place, keeping a brothel are not allowed ( Weitzer, 2009).

In South Africa, Section $11(\mathrm{~A})$ of the criminal procedure Act defines the crime of prostitution as follows: "person $($ " $A$ ") who unlawfully and intentionally engages the services of a person 18 years or older ("B"), for financial or other reward, favour or compensation to $B$ or to a third person (" $C$ ")- for the purpose of engaging in a sexual act with $B$, irrespective of whether the sexual act is committed or not; or by committing a sexual act with $\mathrm{B}$, is guilty of engaging the sexual services of a person 18 years or older."

Sexual offences are also criminalised by range of other laws and by-laws that also impact on sex work. The 
highest Court in South Africa, the Constitutional Court had said that the law applied to male as well as female prostitutes and so was "gender neutral".

The above stated section categorises the crime as prostitution. Prostitution is briefly defined as "sex for reward". Existing literature revealed that prostitution is mankind's oldest profession, having been practiced throughout recorded history (Ringdal, 2005). From the legal perspectives, the phenomenon may be viewed from different dimensions, while some countries consider the act illegal; others do not (de Zalduondo, 1991). In Canada, accepting money in return for sex is not illegal in Canada, but most related activities are (Martell, 2012).

The law may hold the view that prostitution should not be punished at all, but should be allowed without any interference (Zatz, 1997). Such an approach is unacceptable in almost all societies, "for the following reasons: prostitution promotes sexual licentiousness and immorality in general; contributes to the spread of venereal diseases, degrades women; and leads to other crimes closely connected to prostitution, such as intimidation, corruption, dealing in and using drugs" (Richards, 1979).

The law may prohibit prostitution in all its forms and on all levels (Farrior, 1997). The objection to such an approach is that no statute has ever been able to change human nature. Experience has taught that such an absolute prohibition could never work in practice (Overall, 1992). A large part of society will always find ways to satisfy its sexual urges, and legal provisions will not deter such persons or make it impossible for them to do so ( McAnany, 2010). Moreover, there is merit in the argument often advanced that the law should not criminalise actions of two adults performed in the private of their homes or rooms and with mutual consent, which does not cause any harm to any other person or society (Tong, 1984).

The argument in favour of this is that the act is not harmful to an individual victim but harmful to a wider society or public order; this is classified as 'victimless crimes (Scoular and O'Neill, 2007). Therefore using criminal sanctions as social tool to deal with it may not produce the desired result especially where the parties involved have tacitly consented to perpetrate the act. It is often referred to as consensual crimes or public order offences, "crime which involves acts that interfere with the operations of society and the ability of people to function efficiently." (Garland, 2001). Moral offences such as sex work, homosexuality and nudity accompanied with drug use have been considered in this category and their criminalisation challenged on both minimalist and utilitarian grounds (Goodyear, 2009).

There could be a compromise between the two approaches described above. "The two approaches set out above may be described as representing the two extreme approaches to the subject. Accordingly, prostitution is allowed, but its practice is curbed, first, by means of administrative measures, such as the licensing of prostitutes and brothels, and in some cases even the drawing up of geographical borders within which they have to operate" (Jeffreys, 2008). "A second way of curbing free prostitution is by enacting measures which make it difficult for prostitute to advertise their services; prohibiting the running of a brothel; prohibiting people from bringing would-be customers into contact with prostitutes; or prohibiting people from enticing, for example, woman, especially young and destitute woman, to become prostitutes" (Hindle el al. 2003). According to this third approach, it is usually not a crime to be a prostitute or to have intercourse with a prostitute, but their operations are severely hampered in practice (Puiszis, 2012).

Before 1988, South Africa law, broadly speaking followed the third approach set out above, however, in 1988 surprisingly, "the law governing prostitution was amended in such a way that the "compromise approach" was replaced by a total prohibition on prostitution." Thus, since 1988, South African law favoured the second approach set out above.

This resonates the stance of the Canadian Prime Minister who said that "prostitution is bad for society and harmful to communities, women and vulnerable persons," she said."We continue to see a social need for laws to control prostitution and its effects on society." (Martell, 2012).

With regard to effective regulation of prostitution through political or legal frameworks, observation of Goodyear (2009:1) is apt "Political systems have attempted to control and regulate the exchange of sexual activity for commodities and services since the beginning of recorded history. What they all have in common is a singular lack of success in doing so, which leads to the question of whether this is properly a legal, commercial, social or moral issue, and whether it is even intrinsically problematic at all. These include those few countries that have completely prohibited it (United States for example) and even the most draconian measures of all, those of post-war communist China, which involved incarceration and "moral rehabilitation."

The majority decision is surprisingly conservative in its approach to enforcing morality, and it is difficult to reconcile the majority judgements with the liberal attitude of the very same court in respect of the consensual sex between people of the same sex in National Coalition for Gay and lesbian Equality v Minister of Justice (afore mentioned) 19982 SACR 553 (CC)

The entire law at present regarding the criminalisation of prostitution is an anachronism (Svanström, 2005). One merely has to glance at the numerous postures in the press to realise how many women, and also men, advertise their 
sexual "services" to realise that the decision in Jordan, according to which prostitution is a crime, is of little or no practical effect. These advertisements might not expressly speak of sex, but only somebody who is a complete stranger to the ways of the world would fail to understand their implicit sexual connotations. Nevertheless, prosecution for prostitution are extremely rare.

\section{The Concern}

The concern is that the trade is associated with a lot of vices especially when children and women are physically and sexually abused. Some of the victims entered the trade as adolescents between the ages of ages 12-14. Prostitution is usually done by mostly by women who did not choose the work voluntarily, and survivors imply those who have escaped harrowing ordeals as sex workers. Sometimes, these victims are tricked or forced to be involved in the act of prostitution by pimpsor traffickers. Supports of parents also enlisted in some cases due to financial commitments-debts repayments. In the course of the practice, victims are usually introduced to drugs and other criminal activities. Some may want to exit the sex trade but are unable to due to vows or illegal contracts they have entered into with the traffickers. The customers maltreated their clients-prostitutes, sometimes viciously. Thus, these customers are sometimes labelled as prostitute users, barterers, and sexual predators.

\section{Should Sex Workers be Eligible for Protection Under the Law?}

A recent decision of the Ontario court in Canada has emphasised the need for prostitutes to protect themselves by hiring guards and even working from a brothel (Martell, 2012). The court struck down a national law that outlawed brothels, a partial victory for those that contend that Canada's laws put sex workers in harm's way. The implication of this is that the law now protects the prostitutes which translate to accepting legalized brothels of the sort found in Nevada (Martell, 2012).

In the recent case of Canada (Attorney General) v. Bedford, 2012 ONCA 186, an Ontario's Court of Appeal found the laws violated the constitutional rights of sex workers by preventing them from taking safety precautions such as hiring bodyguards or working out of their own homes

The implications of the court's ruling is aptly explained by Andrea (2012), thus "This ruling, having considered a wealth of evidence presented, clearly states that specific provisions of Canada's Criminal Code violate fundamental Charter rights of people working in the sex trade. Legal decisions which exclude morality, uphold Charter rights of individuals stigmatized by their work, which allow women to protect themselves from violence, and which encourage solidarity among women workers are decisions to be celebrated by feminists."

However, when the court in South Africa in the case of Kylie v CCMA 20104 SA 383 (LAC) handed down its decision confirming illegality of sex work, Selala (2011) expressed the view that "Sex work is illegal in South Africa, yet it exists. It is not difficult to imagine how many cases would flow into the labour litigation mainstream following this judgment, the nature of the cases that the CCMA Commissioners are likely to be confronted with on a daily basis, and the reaction of the Commissioners upon receipt of such cases. One can think of quite a number of examples of cases other than those involving sex workers which the CCMA Commissioners and the South African community at large would frown upon, or even hate to think of them being dealt with by the legitimate legal structures of government.

\section{Conclusion}

No matter what angle the problem or the issue of sex trade is perceived, it is difficult to justify the continuation of the trade. There have also been attempts to categorise the trade those who function within the trade as performing works that should be recognised under the law. Different courts from different jurisdictions have continued to establish whether a prostitute is a worker whose rights ought to be protected under the employment laws. For those countries where the trade has been recognised and backed up with appropriate legislations, sex workers can seek protection and redress. However, for states that perceive the trade as illegal, it becomes a daunting task for the judicial system to ensure their protection, this is because, the court will not enforce illegal contract. Even though some states have attempted to control or prohibit the trade, the issue of two consenting people perpetrating the act makes it difficult to eradicate or for the act to be punishable. Often times, prosecution and conviction failed because of lack of cogent evidence. Worse still, those who are supposed to enforce the laws on prostitution have been found to be actively patronising the trade sometimes with force and intimidation. Arrested prostitutes sometimes secured their freedom by succumbing to sexual advances of the law officials. From all perspectives, prostitutes are on the receiving end. The issues surrounding sex trade will therefore 
continue to be in the limelight whether at the local or international arena. It is against the backdrop of this that this paper describes in perspectives the phenomenon of sex work.

\section{References}

Allison Martell 2012. Canada court ruling would allow legal brothels. From Reuters. (Retrieved March 27, 2013).

Andrea A 2012. Beauvoir Institute statement on court decision related to prostitution. (Retrieved March 30, 2013).

Bassham B 2012. Legislating Morality: Scoring the Hart-Devlin Debate after Fifty Years, Ratio Juris, 25 (2):117-132.

BBC 2008. British Broadcasting Corporation, SA prostitution plans condemned. http://news.bbc.co.uk/1/hi/world/africa/7509357.stm. (Retrieved October, 11, 2012).

BBC News 2009. New Norway Law Bans Buying of Sex. From www.news.bbc.co.uk. (Retrieved September 21, 2012).

Bullough V, BulloughB 1978. Prostitution: An Illustrated Social History. http://prostitution.procon.org/view.source.php?sourcelD=3647. (Retrieved December 19, 2013).

Cohen -R 2006. Migration and Its Enemies: Global Capital Migrant Labour and the Nation-State, Ashgate Publishing Ltd. Hampshire, UK.

de Zalduondo BO 1991. Prostitution viewed cross-culturally: Toward Recontextualizing sex work in AIDS intervention research, The Journal of Sex Research, 28(2):223-248.

Farrior S 1997. The international law on trafficking in women and children for prostitution: Making it live up to its potential. From http://papers.ssrn.com/sol3/papers.cfm?abstract_id=886444. (Retrieved April 19, 2013).

Garland D 2001. The culture of control: Crime and social order in contemporary society, Oxford University Press, UK.

Gelb S 2004. Inequality in South Africa: Nature, causes and responses. From sarpn.org. (Retrieved March 4, 2012).

Goodyear M 2009. Controlling Loose Women: International trends in the regulation of the exchange of sexual services. From cybersolidaires.typepad.com.btnG=\&hl=en\&as_sdt=0\%2C5. (Retrieved February 4, 2013).

Hindle K, Barnett L, Casavant L 2003. Prostitution: A review of legislation in selected countries. From http://publications.gc.ca/site/archivee- R/LoPBdP/PRB-e/PRB0329-e.pdf. (Retrieved January 16, 2012).

Hubbard P 2001. Sex zones: Intimacy, citizenship and public space Sexualities. From sexualities.sagepub.com. (Retrieved November 4, 2012).

Hunt A 1999 . Governing morals: A social history of moral regulation, Cambridge University Press, Cambridge, UK.

IAN, 1998. Internet Ancient History Sourcebook. From http://prostitution.procon.org/view.source.php?sourcelD=3647. (Retrieved December 19, 2013).

Jeffreys S 2008. The idea of prostitution, Spinfex Pty, North Melbourne, Australia.

Katyal S, William M 2006. Sexuality and sovereignty: The global limits and possibilities of Lawrence, Fordham Law Legal Studies Research paper, 14(909523):1429-1442.

Kelly L, Regan L, Britain G 2000 . Stopping traffic: Exploring the extent of, and responses to trafficking in women for sexual exploitation in the UK. From andreanetwork.pbworks.com. (Retrieved May 6, 2012).

McAnany E 2010. Communication for Development and Social Change: New Millennium, Centre for the Study of Communication and Culture, 29(3):1-19.

Melossi D 2000. Changing representations of the criminal, British Journal of Criminology, 40(2): 296-320.

Mizuta T, Mulvey-Roberts M 1994. Perspectives on the History of British Feminism: The Rights of Married Women. http://prostitution.procon.org/view.source.php?sourcelD=3647. (Retrieved December 19, 2013).

Overall C 1992. What's Wrong with Prostitution? Evaluating Sex Work, Signs 17(4):705-724.

Plauché GA 2006. Moral Legislation and Democracy: The Devlin-Hart-Dworkin Debate Revisited. From gaplauche.com. http://gaplauche.com/docs/dhdapsa2006.pdf. (Retrieved June 16, 2012).

Puiszis SM 2012 . Tinkering With the First Amendment's Protection of Student Speech on the Internet, Marshall Journal of Computer \& Information Law, 29:167-179.

Raz J 1986 .The morality of freedom, Oxford university Press, UK.

Reuters 2009. Pressured by Sex Workers, Taiwan OKs Prostitution. From www.reuters.com. (Retrieved June 24, 2009).

Richards DAJ 1979. Commercial Sex and the Rights of the Person: A Moral Argument for the Decriminalization of Prostitution, University of Pennsylvania Law Review, 127(5):1195-1287.

Ringdal NJ 2005. Love for sale: A world history of prostitution, Grove Press, New York, USA.

Scoular J, O'Neill M 2007. Regulating Prostitution Social Inclusion, Responsibilization and the Politics of Prostitution Reform, British Journal of Criminology, British Journal of Criminology, 47 (5):764-778.

Selala DJ 2011.The enforceability of illegal employment contracts according to the labour appeal court: comments on kylie v ccma 2011 4 SA 383 (LAC), Potchefstroom Electronic Law Journal, 14(2). From http://www.ajol.info/index.php/pelj/article/view/67220. (Retrieved December 20, 2013).

Svanström Y 2005. Through the Prism of Prostitution: Conceptions of Women and Sexuality in Sweden at Two Fins-de-Siècle, Nordic Journal of Feminist and Gender Research, 13(1): 48-58.

Tomsen S 2013 .Violence, prejudice and sexuality, Routeledge, London, UK.

Tong R 1984 . Women, sex, and the law, Rowman Littlefield Publishers Ltd, Maryland, USA.

Weitzer R 2009. Sex for sale: Prostitution, pornography, and the sex industry, Routledge, New York, USA. 
Zatz ND 1997. Sex work/sex act: Law, labor, and desire in constructions of prostitution, Signs, 22(2):277-308. 